\title{
The symposium: Fundamentals of Criminal Law
}

\author{
Introduction
}

\author{
Af Anne Marie Anfinsen, Linda Gröning, Jørn Jacobsen \\ og Annika Suominen
}

The symposium Fundamentals of Criminal Law was held in Bergen on the $9^{\text {th }}$ and $10^{\text {th }}$ of June, 2011. This symposium was the result of collaboration between two of the current research projects in criminal law at the Faculty of Law, University of Bergen; the research project Criminal Law Theory: A New Norwegian Approach and the research project Strafferettssystemets funksjonalitet, in English: Functionality in the Criminal Justice System. Both research projects are funded by Bergen Research Foundation. For further information on the research projects, see their homepages at www.uib.no/jur.

The symposium was composed of contributions from both researchers involved in the mentioned research projects and distinguished foreign guests. The symposium addressed five overall topics, with two lectures in each. The topics and their respective presentations were:

1) Criminal Law and Philosophy (chaired by Ass. Prof. Ragna Aarli, Bergen)

1. Prof. Wolfgang Frisch, Freiburg: The Influences of Philosophy On the Development of Criminal Substantive Law and Criminal Procedure in Europe

2. Prof. Magnus Ulväng, Uppsala: Criminal Intent \& the Demise of Dualism

2) Concepts in the Criminal Law (chaired by Ass. Prof. Eivind Kolflaath, Bergen)

1. Postdoc. Jørn Jacobsen, Bergen: The Concepts of Criminal Law

2. Prof. Dan Frände, Helsinki: The Concept of Rechtsgut - A Finnish Perspective

3) The Criminal Justice System (chaired by Prof. em. Nils Jareborg, Uppsala)

1. Postdoc. Linda Gröning, Bergen: Notes on the Basic Structure of the Criminal Justice System

2. Prof. Per Ole Träskman, Lund: Functionality in the Criminal Justice System: A Nordic Perspective

4) The Criminal Procedure (chaired by Dean, Prof. Asbjørn Strandbakken, Bergen) 
1. Prof. em. Heike Jung, Saarbrücken: "Justice Must Seen to be Done"

2. Postdoc. Joanna B. Banach-Gutierrez, Bergen: The Concept of Due Process: What Kind of "Doing Justice" in the Contemporary Criminal Proceedings?

5) Current Challenges to the European Criminal Law Science, (chaired by Researcher Annika Suominen, Bergen)

1. Senior Lecturer Marianne Wade, Birmingham: The European Public Prosecutor as a Challenge for the Legitimacy of European Criminal Justice - can there be criminal justice without a balanced system to produce it?

2. Comment: Prof. Petter Asp, Stockholm.

In addition, the symposium gathered a number of researchers from Nordic and other European countries, which significantly contributed to the stimulating discussions following the different presentations.

Doing science is to a large extent comparable to living in Bergen: One is constantly facing a new height to climb, often in cloudy weather. Sometimes, however, one gets to a point beyond the clouds where one's horizon broadens. This symposium confirmed both this character of science and of Bergen: At least we reached new heights and insights during it. We would hereby like to express our gratitude to all those who in different manners contributed to a successful arrangement. And we hereby present some of the papers delivered at the symposium so that more than those who were present in Bergen in June are able to take part in them. 